\title{
Alat Kontrol Temperatur Menggunakan Panel Surya untuk Mengurangi Tingkat Kematian pada Pembenihan Ikan Lele di Kabupaten Kediri
}

Eko Yohanes Setyawan ${ }^{1}$, Yusuf Ismail Nakhoda ${ }^{2}$, Basuki Widodo ${ }^{2}$, Choirul Soleh $^{2}$

1, 2 Institut Teknologi Nasional Malang

\begin{tabular}{l} 
Article History \\
\hline Received 27.06 .2019 \\
Received in revised form \\
10.09 .2019 \\
Accepted 18.10 .2019 \\
Available online 28.10 .2019
\end{tabular}

ABSTRACT

TEMPERATURE CONTROL DEVICES USING SOLAR PANELS TO REDUCE MORTALITY RATES IN CATFISH HATCHERIES IN KEDIRI REGENCY. Pelemahan District, Kediri Regency is one of the centers of catfish breeding that is visited by many industry players in the field of catfish enlargement for consumption. This nursery has been done for a long time in this region because of the good geographical and topographic conditions for catfish hatchery, so many entrepreneurs' enlargement catfish for the consumption of buying catfish seeds in Kediri Regency. From the results of a survey of the Malang National Institute of Technology's dedicated team for Pelemahan Subdistrict, there were several problems with the catfish breeding business, namely poor environmental conditions so that the number of dead fish caused by temperature changes caused the fish to become stressed. Water quality is a factor that must be cleaned because it is contaminated with catfish food and catfish feces. So that water circulation needs to be done, so a tool is made that can reduce the temperature of the water in the pool between $28-30{ }^{\circ} \mathrm{C}$. The workings of the tool first measure the temperature of the water in the pond when the high temperature of the water pump will automatically turn on, until the temperature drops and to maintain clean water in the pool the water pump automatically turns on every three hours. Because the place of catfish is maintained which is sometimes far from home and to facilitate the maintenance of catfish, this tool is made easy to move, and using solar energy that is easily available. From the results of observing using a temperature controller in the pool can reduce the death rate due to stress and lack of oxygen.

KEYWORDS: Catfish, Solar Panels, Temperature.

This is an open access article distributed under the terms of the Creative Commons Attribution 4.0 International License, which permits unrestricted use, distribution, and reproduction in any medium, provided the original work is properly cited. C 2019 Eko Yohanes Setyawan, Yusuf Ismail Nakhoda, Basuki Widodo, Choirul Soleh.

\footnotetext{
${ }^{1}$ Corresponding author: Institut Teknologi Nasional Malang; Jl. Sigura-Gura No. 2, Malang; Email: yohanes@ lecturer.itn.ac.id
} 


\section{PENDAHULUAN}

Kebutuhan masyarakat akan daging lele konsumsi semakin hari terus meningkat, terutama ikan lele yang mempunyai kelebihan dari lele non organik. Ikan lele organik kaya akan protein, rasanya sangat enak, gurih, lezat, harganya terjangkau dan sangat bermanfaat bagi kesehatan, sehingga banyak digemari oleh masyarakat. Saat ini Kabupaten Kediri bisa dikatakan salah satu sentra budidaya Ikan Lele terbesar. Karena banyaknya permintaan lele untuk pembibitan dan konsumsi.

Budidaya ikan lele memang usaha yang sangat menguntungkan, karena selain hasilnya dapat dimakan sendiri, sisanya dapat dijual dan menjadi tambahan penghasilan bagi yang membudidayakannya (Sofinisa, 2015). Dalam usaha budidaya ikan lele ada dua kegiatan besar yang harus ditingkatkan secara bersamaan yaitu usaha pembenihan dan pembesaran. Kedua kegiatan ini tidak dapat dipisahkan dalam prosesnya. Sebab kegiatan pembenihan merupakan kegiatan awal di dalam budidaya. Tanpa kegiatan pembenihan kegiatan yang lain seperti pembesaran tidak akan terlaksana.

Salah satu faktor yang menentukan adalah tersedianya benih yang memenuhi syarat, baik kualitas, kuantitas, maupun kontinuitasnya (Alami, 2016). Benih yang tersedia dalam jumlah banyak tetapi kualitasnya rendah hanya akan memberatkan petani pembesaran karena hasilnya tidak seimbang dengan kuantitas pakan yang diberikan. Sementara benih yang berkualitas bagus tetapi jumlahnya terbatas juga tidak akan meningkatkan produksi usaha pembesaran, karena akan timbul kekurangan benih yang cukup serius. Ketersediaan benih merupakan faktor yang sangat vital dalam usaha pembesaran.

Seperti usaha pembibitan yang sudah dilakukan di Kabupaten Kediri terdapat lima tahapan yaitu embrionik, larva (benih), juknil (benih yang mendekati dewasa), benih dewasa, dan fase tua. Pada fase embrionik dan larva (benih), ikan dalam keadaan krisis (gawat) terhadap lingkungannya, sehingga untuk mempertahankan kelangsungan hidupnya, benih harus berada dalam lingkungan yang cocok/baik, pada tahapan inilah yang terpenting yaitu menjaga temperatur lingkungan tetap pada temperatur $28-30^{\circ} \mathrm{C}$, sehingga dibutuhkan alat yang mampu mendeteksi temperatur air kolam pembibitan ikan lele. Kemudian perawatan agar benih lele berkembang cepat dan seragam dengan mengkelompok berdasarkan ukurannya agar tidak saling memakan.

Pompa pada pembenihan ikan lele digunakan untuk mengalirkan air temperatur tinggi keluar kolam dan menggantikan dengan air dingin yang diambil dari sumber air tanah menggunakan panel surya. Panel surya pada prinsipnya memanfaatkan intensitas matahari untuk dirubah menjadi energi listrik (Djamain, 2000; Bachtiar, 2006). Energi listrik dari solar cell tersebut langsung digunakan sebagai energi untuk menggerakkan pompa air. Pompa air de ini berfungsi sebagai mensirkulasikan air pada kolam pembenihan, agar air kolam tersebut tetap dalam kondisi jernih dan kaya oksigen. Penggunaan pompa dc ini bertujuan agar dalam merangkai sistem energi listrik yang dibutuhkan dapat dengan mudah. Hal ini dikarenakan energi listrik dari solar cell memiliki arus listrik Direct Current (DC). Agar dapat digunakan langsung tanpa merubah arus DC menjadi AC maka penggunaan pompa air menggunakan arus DC. Berdasarkan uraian di atas, perlu adanya perancangan sistem alat sirkulasi air pada kolam pembenihan ikan dengan menggunakan panel surya (Prabowo, Triwiyatno, \& Sumardi, 2013). 


\section{METODE PELAKSANAAN}

Memberikan pendidikan dan pelatihan penerapan ilmu dan teknologi dalam penggunaan alat panel surya. Disini akan dikenalkan komponen-komponen dan alat pembuatan panel surya serta bagaimana cara merakit panel surya dan dihubungkan dengan komponen-komponen lainnya serta penggunaanya ketika dipakai untuk pembibitan ikan lele yang digunakan untuk mengontrol terperatur air di dalam kolam pembibitan ikan lele. Dimana panel surya dirangkai secara seri (1 baris panel dirangkai seri) dan output dari setiap baris dirangkai paralel. Output dari kesatuan panel surya adalah arus searah (DC) digunakan untuk kebutuhan energi pompa, yang nantinya akan diubah menjadi arus bolak balik (AC) untuk keperluan energi manajemen kolam. Merangkai suatu panel surya untuk penggunaan manajemen kolam pembibitan ikan lele, memerlukan beberapa perangkat tambahan:

1) Charge controller

2) Baterai atau accumulator

3) Inverter untuk mengubah menjadi AC digunakan untuk menghidupkan sensor dan Termokontroler

4) Pompa air

Arus DC dari panel surya akan mengalir menuju charge controller. Pada charge controller arus atau muatan dapat dikontrol untuk mengalir menuju baterai (pengisian muatan baterai) ataupun langsung menunu inverter DC/AC untuk digunakan menghidupkan pompa air. Seperti terlihat pada gambar 1. Desain alat kontrol temperatur portable.

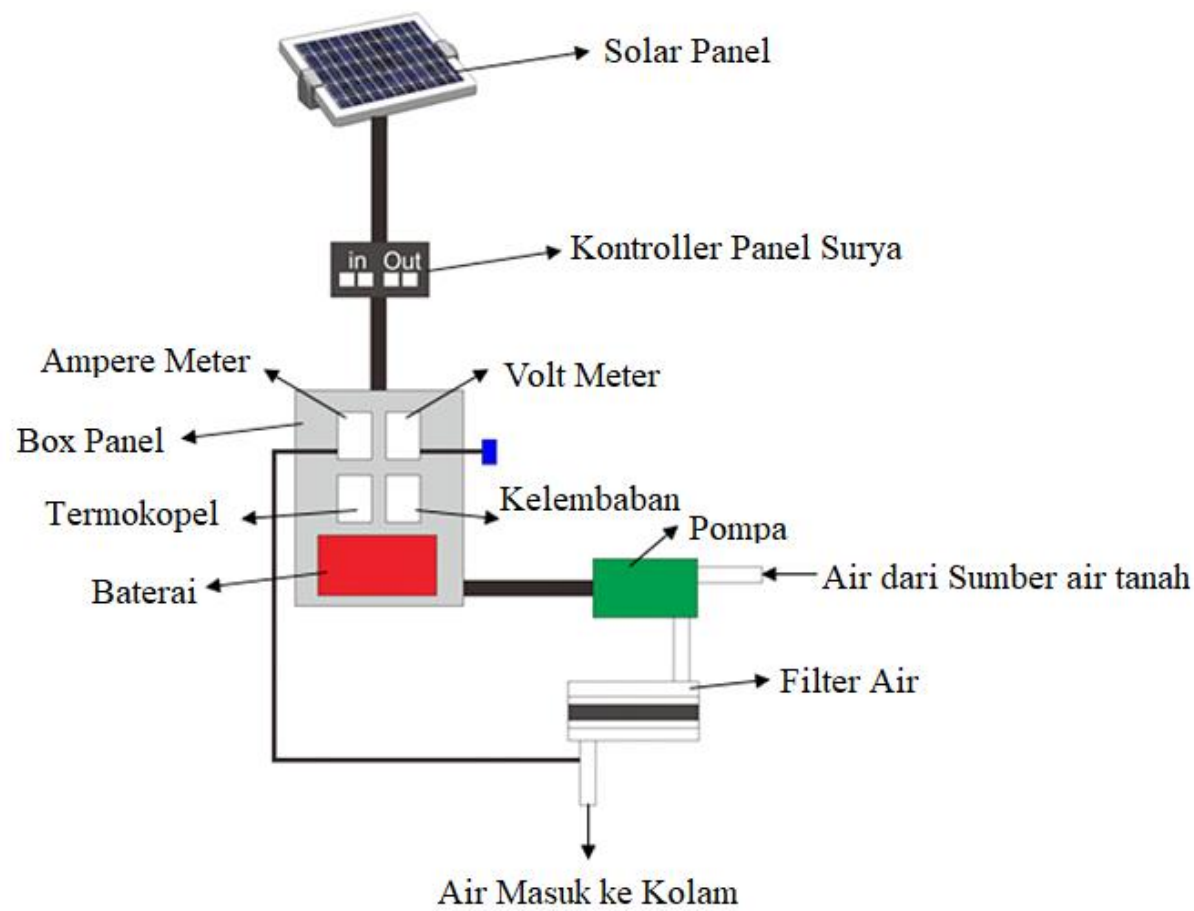

Gambar 1. Desain Alat Kontrol Temperatur Portable 


\section{Cara kerja :}

1) Sistem alat manajemen sirkulasi air kolam menggunakan solar cell yang meliputi beberapa komponen, panel surya, controller, box panel, temperature control, humidity control, battery, pompa dan filter air.

2) Sistem kontrol dalam satu box panel yang meliputi kontrol temperatur, kontrol humidity, kontrol arus battery, kontrol voltase battery.

3) Filter air yang memiliki tiga lapisan meliputi, lapisan pertama spon, lapisan kedua arang aktif, dan lapisan ketiga spon

Sistem sirkulasi air kolam dimana yang dimaksud air kolam masuk melalui pompa dilanjutkan ke filter air dimana didalam filter air, air disaring melalui tiga tahapan yaitu, spon pertama, arang aktif dan spon kedua, kemudian air dikembalikan ke kelom dengan melewati pipa yang sudah dilengkapi sensor temperatur.

\section{HASIL DAN PEMBAHASAN}

Dari hasil percobaan menggunakan alat kontrol temperatur pada pembibitan ikan lele yang berada di Kabupaten Kediri didapatkan temperatur yang cocok yaitu pada temperatur $28-30^{\circ} \mathrm{C}$. pada temperatur tersebut bibit ikan lele tidak mengalami stres yang disebabkan naik turunnya temperatur yang signifikan pada jam 11.00 sampai jam 13.00 pada jam-jam tersebut pompa bekerja secara maksimal, karena temperatur cukup tinggi yang disebabkan oleh intensitas matahari yang tinggi. Intesitas matahari akan mulai turun pada jam 14.00 dengan rata-rata $30^{\circ} \mathrm{C}$. Alat yang digunakan untuk mengontrol temperatur disajikan seperti gambar 2 .

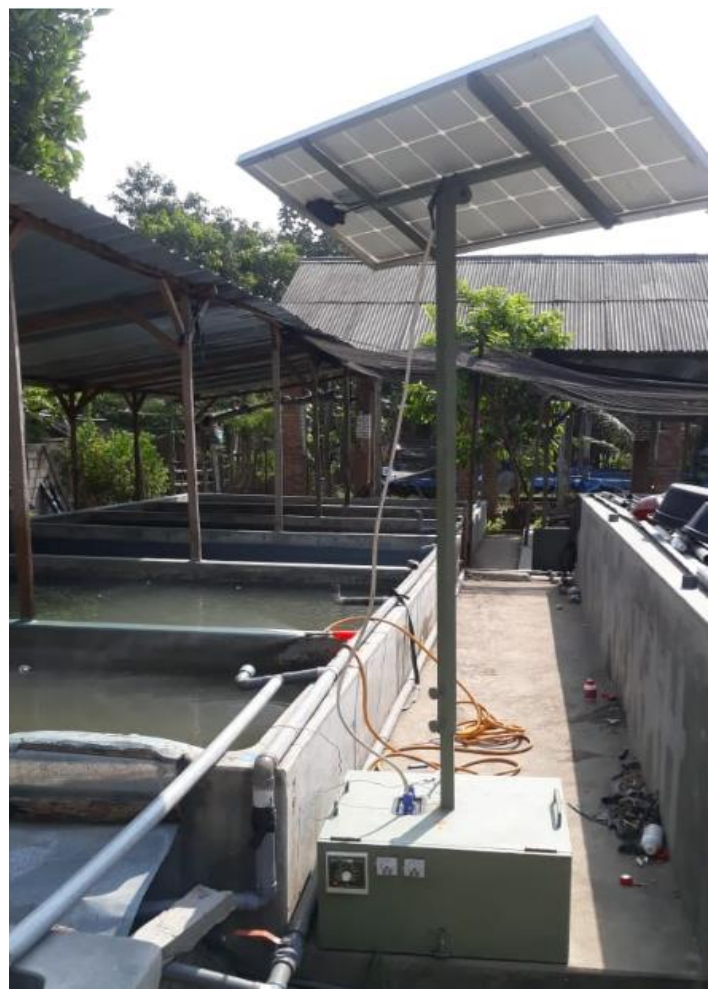

Gambar 2. Alat Kontrol Temperatur Portable 
Alat kontrol temperatur portable, dimana alat ini bisa berpindah tempat dengan mudah, meskipun tidak ada aliran listrik dari PLN alat ini bisa bekerja dengan maksimal karena menggunakan panel surya yang memanfaatkan intensitas matahari menjadi energi listrik (Catalin, 2010). Alat kontrol temperatur ini memang sengaja di disain secara portable untuk memudahkan petani pembibitan ikan lele untuk mengembangkan di daerah yang belum dialiri listrik PLN maupun tempatnya yang jauh dari rumah tetap bisa melakukan pembibitan ikan lele.

Pada gambar 2. Terlihat alat kontrol temperatur portable yang digunakan untuk menggerakan pompa, sensor dan alat kontol lainnya. Untuk memudahkan mengetahui peralatan yang digunakan dan fungsi masing-masing alat yang dipakai dapat dijelaskan seperti dibawah ini:

1) Panel surya; Digunakan untuk sumber energi listrik dengan memanfaatkan dari intensitas matahari. Kapasitas panel surya.

2) Controller; Digunakan untuk mengontrol arus masuk dari solar cell dan arus keluar ke battery.

3) Box panel; Berfungsi sebagai cover atau pelindung temperatur kontrol, humidity kontrol, amper meter, volt meter dan battery.

4) Temperature control; Digunakan untuk mengontrol temperatur air dengan menggunakan sensor temperatur (termokopel) tipe $\mathrm{K}$.

5) Humidity control; Digunakan untuk mengontrol kelembaban udara sekitar kolam.

6) Ampere meter; Digunakan sebagai pengontrol arus battery.

7) Volt meter; Digunakan sebagai pengontrol voltase battery.

8) Battery; Digunakan sebagai menyimpan arus listrik dari panel surya.

9) Pompa DC; Mensirkulasikan air kolam.

10) Filter air; Berfungsi sebagai menyaring air kolam. Didalam filter air ini terdapat 3 lapisan yaitu, lapisan 1 spon, lapisan 2 arang aktif dan lapisan 3 spon.

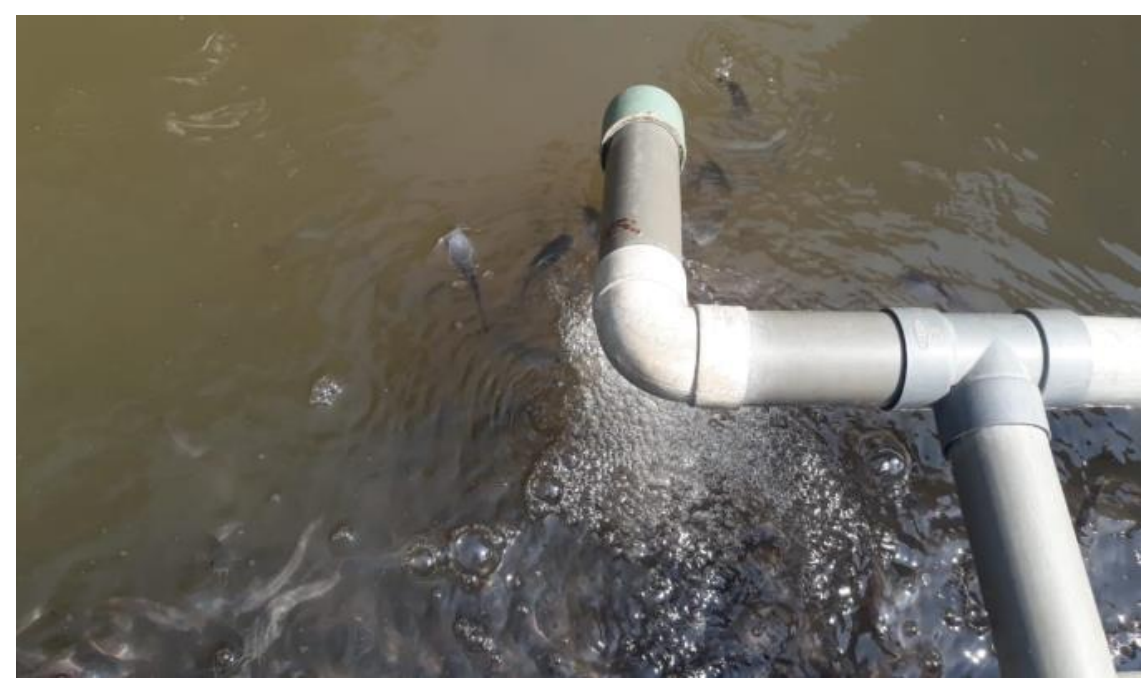

Gambar 3. Sirkulasi Air 
Gambar 3 menunjukan sistem sirkulasi air dengan bantuan pompa air dengan cara memasukan air baru kedalam kolam, sedangkang air yang lama secara otomatis keluar melalui pipa PVC yang sudah diatur ketinggian air didalam kolam. Proses ini sangat penting untuk membantu ikan mendapat oksigen, karena ikan tidak dapat mengambil udara secara langsung dari udara sehingga harus dibantu dengan mensirkulasikan air. Dengan begitu oksigen terlarut masuk ke dalam air digunakan untuk memenuhi kebutuhan oksigen ikan lele didalam kolam. Kebutuhan oksigen pada pembibitan ikan lele berbeda-beda sesuai dengan pengaruh lingkungan seperti jumlah ikan didalam kolam, temperatur, ukuran ikan lele dan masih banyak lagi yang mempengaruhinya (Gunawan, 2014).

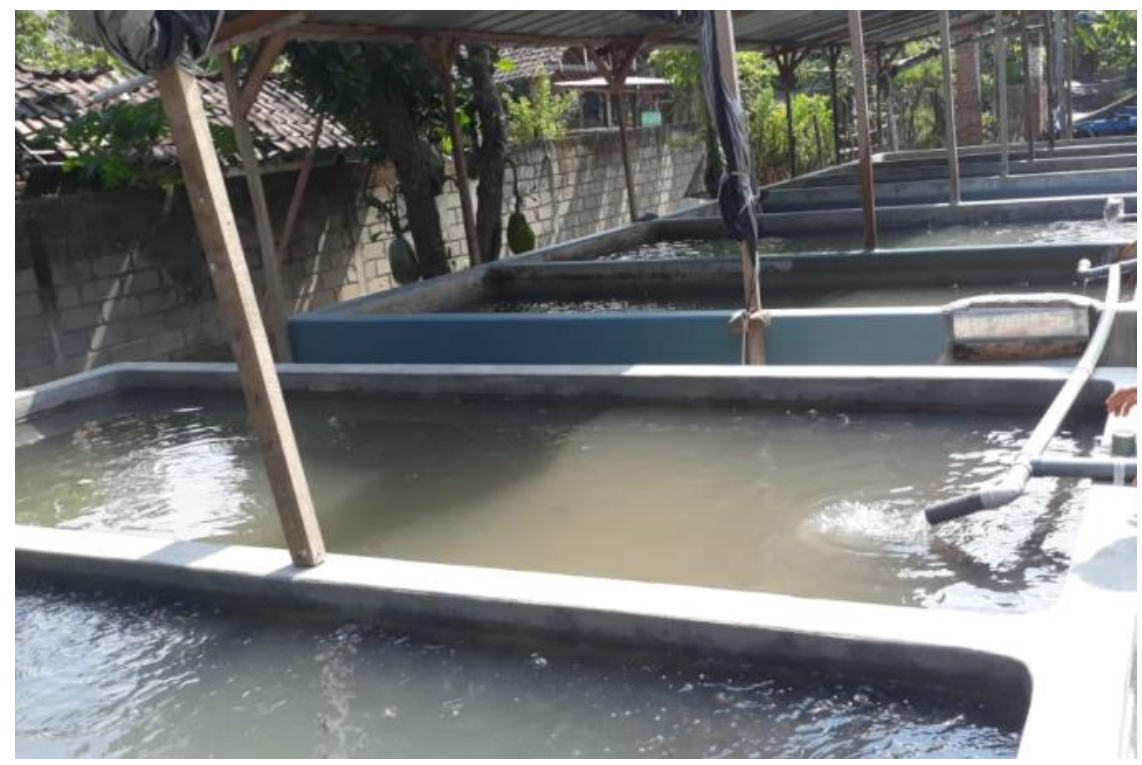

Gambar 4. Kolam Pembibitan İkan Lele

Pada pembibitan ikan lele dibutuhkan banyak kolam karena ikan lele cenderung memakan sesama ikan yang ukuranya lebih kecil. oleh sebab itu dibutuhkan banyak kolam untuk melakukan pembibitan ikan lele seperti pada gambar 4. Kolam pembibitan ikan lele agar jumlah ikan lele tidak banyak berkurang pasca panen karena dimakan sesama ikan lele yang lebih besar, karena lele bersifat kanibal (Rosmawati \& Muarif, 2010).

Pada pembibitan ikan lele yang ada di Kabupaten Kediri rata-rata menjual ikannya pada ukuran kepala ikan 6-7 cm. waktu yang dibutuhkan untuk pembibitan kurang lebih 75 hari. Dengan biaya yang dikeluarkan kurang lebih mencapai 15.000.000,00 untuk ikan lele 300.000.000, sehingga petani pembibitan ikan lele dalam kurun waktu -/+ 3 bulan bisa mendapat keuntungan 15.000.000,00, dengan asumsi harga ikan lele 100 per ekor. Dari nilai tersebut maka dibutuhkan ketahanan hidup ikan lele sampai 75 hari agar bisa dijual ke pasar untuk pembesaran, yang nantinya menjadi lele komsumsi yang dijual di pasarpasar pada umumnya. Oleh sebab itu sangat dibutuhkan alat yang bisa mengontrol temperatur (Setyawan, Djiwo, \& Sugiarto, 2017; Setyawan et al, 2017), yang dilanjutkan untuk mensirkulasikan air kolam pada pembibitan ikan lele. Temperatur air kolam yang dibutuhkan antar $28-30^{\circ} \mathrm{C}$ agar lele tidak mengalami stress akhirnya mati. Karena perubahan temperatur yang berubah-ubah selain itu juga dibutuhan oksigen terlarut didalam kolam. Dengan cara mengganti sebagian air kolam dengan air bersih, pada 
proses ini secara otomatis akan membuat gelembung-gelembung di sekitar aliran air bersih.

\section{SIMPULAN}

Pembenihan ikan lele merupakan salah satu usaha pertanian yang cukup menjajikan, dimana usahan ini bisa mendapat keuntungan sekitar 50\% dari modal yang sudah dikeluarkan. Pembibitan lele ini membutuhkan ketelitian yang tinggi karena rentan akan mati, faktor tertinggi yang menyebabkan kematian karena temperatur yang berubah-ubah sehingga meyebabkan ikan menjadi stress. Sehingga dibuat sebuah alat yang mampu mengontrol temperatur air kolam sebesar $28-30^{\circ} \mathrm{C}$ dan juga untuk memenuhi kebutuhan oksigen. bila temperatur air cukup tinggi dilam kolam, akan digantikan dengan air yang baru. dengan bantuan pompa, untuk memompa air tanah masuk ke dalam kolam pembibitan ikan lele. sehingga terbentuk gelembung-gelembung disekitar aliran air. Alat ini digerakkan dengan menggunkan solar panel agar mudah untuk dipindahkan ke tempat yang belum ada aliran listrik.

\section{REFERENSI}

Alami, H. M. T. (2016). Pengaruh umur terhadap penjantanan larva ikan lele dumbo (clarias gariepinus) yang direndam menggunakan hormon metil testoteron alami. Jurnal Medika Veterinaria Vol, 10(1), 41-44.

Bachtiar, M. (2006). Prosedur perancangan sistem pembangkit listrik tenaga surya untuk perumahan (solar home system). SMARTek, 4(3), 176-182.

Catalin, A. (2010). Optimal design of the controller for a photopholtaic tracking system using parametric technique. Brasov: Transilvania University of Brasov, Romania.

Djamain, M. (2000). Strategi penerapan energi surya di Indonesia. Malang: Universitas Gajayana.

Gunawan, S. (2014). Kupas Tuntas Budi Daya \& Bisnis Lele. Jakarta: Penebar Swadaya Grup.

Prabowo, Y. A., Triwiyatno, A., \& Sumardi, S. (2013). Perancangan dan simulasi sistem tracking panel surya dua derajat kebebasan menggunakan metode kendali logika fuzzy. TRANSIENT, 2(3), 463-470.

Rosmawati, R., \& Muarif, M. (2010). Kelangsungan Hidup Dan Pertumbuhan Benih Ikan Lele Dumbo (Clarias SP.) Pada Sistem Resirkulasi Dengan Kepadatan Berbeda. Sain Akuatik, 13(2), 1-8.

Setyawan, E. Y., Djiwo, S., \& Sugiarto, T. (2017). Simulation model of fluid flow and temperature distribution in porous media using cylinder convergent and divergent nozzle. International Journal of Technology and Sciences, 1(1), 1-10. 
Setyawan, E. Y., Napitupulu, R. A., Siagian, P., \& Ambarita, H. (2017). Field tests of a natural vacuum solar desalination system using hybrid solar collector. IOP Conference Series: Materials Science and Engineering, 237(1), 1-7.

Sofinisa, A. (2015). Pemberdayaan masyarakat sebagai upaya meningkatkan ekonomi pedesaan (Studi terhadap pemberdayaan peternak lele melalui pendidikan dan pelatihan di Desa Paron Kecamatan Ngasem Kabupaten Kediri). Jurnal Administrasi Publik, 3(11), 1844-1850. 